\title{
Synthesis and Secretion of a Nerve Growth- Stimulating Factor by Neonatal Mouse Astrocyte Cells in Vitro
}

\author{
R. H. TARRIS, M. E. WEICHSEL, JR., AND D. A. FISHER \\ Harbor-UCLA Medical Center, Department of Pediatrics, Perinatal Research Laboratories, Torrance, \\ California 90509
}

\begin{abstract}
Neonatal mouse astroglial cells cultured in a serum-free medium synthesize and secrete a trophic growth factor which resembles nerve growth factor (NGF). The NGF-like factor reacts with antiserum to $\beta$ subunit of NGF ( $\beta$-NGF) and, after labeling with $\left[{ }^{35} \mathrm{~S}\right]$ cystine, migrates similarly to purified mouse $\beta$-NGF in SDS polyacrylamide gel electrophoresis and Sephadex G-100 gel filtration systems. The astrocyte cell NGF-like factor displays $\beta$-NGF-like neurite growth-promoting activity for the clonal rat pheochromocytoma (PC-12) cell line and this bioactivity is blocked by $\beta$-NGF antiserum. These results indicate that NGF-like factor synthesized and secreted by astroglial cells, is similar, if not identical, to $\beta$ NGF from the mouse submandibular gland and further support a potential role for NGF in the central nervous system. (Pediatr Res 20: 367-372, 1986)
\end{abstract}

\section{Abbreviations}

NGF, nerve growth factor

$\beta$-NGF, $\beta$ subunit of NGF

CNS, central nervous system

GCM, glial conditioned medium

SDS-PAGE, sodium dodecyl sulfate-polyacrylamide gel electrophoresis

TCA, trichloroacetic acid

NGF is a protein known to be necessary for the growth and maintenance of sympathetic neurons of the autonomic nervous system, as well as certain sensory neurons of the peripheral nervous system. Recent evidence suggests that there also are significant concentrations of NGF in the CNS. Immunoreactive NGF has been reported in adult brain tissue of several species (1-5), and we have reported finding NGF immunoreactivity in the brain of developing, as well as adult, mice (6). Scott et al. (7) reported finding bioactive NGF in homogenates of CNS tissue from adult mice. Since NGF does not cross the blood brain barrier, CNS NGF is thought to be produced locally. However, the possible site of production has not been clearly elucidated.

NGF has been reported to be synthesized by such cell lines and tissues in culture as Sarcoma 37 and $180(8)$, glioma (9) and neuroblastoma cells (10), 3T3 and L cells (11), rat skeletal muscle cells (12), human fibroblasts (13), chick dorsal root ganglia (14), primary chick fibroblasts (15), and mouse adrenal medulla (16) and heart (17-20), among others. Although human glial cells in

Received September 18, 1985; accepted November 18, 1985.

Send correspondence to: M. E. Weichsel, Jr., M.D., Department of Pediatrics, Building A-17, Harbor-UCLA Medical Center, 1000 West Carson Street, Torrance, CA 90509.

Supported in part by NIH Grants HD-04270 and HD-11303. culture have been reported to release an NGF-like substance (21), there has been little additional direct evidence for the synthesis or release of NGF or NGF-like growth factors from normal brain tissue. In the present report, we describe the synthesis and secretion of an immunoreactive and bioactive NGFlike factor with biochemical characteristics of NGF from cultures of cerebral tissue derived from 1- to 2- and 12-day-old mice. Staining, histological, and growth characteristics suggest that the cultures consist predominantly of astrocytes. These data provide the first direct evidence that an NGF-like factor is produced by astrocytes derived from the neonatal mammalian brain.

\section{MATERIALS AND METHODS}

Cell culture. The cerebral hemispheres were rapidly removed from either 1- to 2- or 12-day-old Swiss-Webster mouse pups killed by decapitation and placed into cold Honegger's Saline D1, pH 7.4 (22) until the dissections were complete. The tissue was finely minced with scissors, washed twice with ice cold Honegger's Saline D 1, and extracted with $0.25 \%$ Viokase (Viobin Corp) in Ham's saline B, pH 7.4, for three 10-min dissociation intervals at $35^{\circ} \mathrm{C}$. Each cell extraction was passed through a 37 $\mu$ nylon sieve to insure a single cell suspension. The suspensions were collected into 50 - $\mathrm{ml}$ centrifuge tubes containing resintreated (23) macromolecular fetal bovine serum protein (FBSPR) (24) and centrifuged at $800 \mathrm{rpm}$ for $10 \mathrm{~min}$ at room temperature. The resultant cell pellet was suspended in Fisher's mouse astrocyte medium (25), modified to contain Delbecco's modified Eagle's medium with $4.5 \mathrm{~g} /$ liter glucose supplemented with biotin $(10 \mu \mathrm{g} / \mathrm{ml})$, selenous acid $(30 \mathrm{nM})$, and FBSP-R $(1 \mathrm{mg} / \mathrm{ml})$. The final osmolality was $320 \mathrm{mOsmol} /$ liter.

A cell density of $2 \times 10^{5} / \mathrm{ml}$ was distributed in $10 \mathrm{ml}$ to culture flasks having a surface area of $75 \mathrm{~cm}^{2}$; the cells were incubated at $37^{\circ} \mathrm{C}$ in humidified $5 \% \mathrm{CO}_{2} /$ air. The cultures were refed on days 3, 6, and 9. On day 9 after feeding, the flasks were placed on a rotary shaker at $35^{\circ} \mathrm{C}$ for $24 \mathrm{~h}(250 \mathrm{rpm})$ to remove over $95 \%$ of the contaminating oligodendroglial cells as described by McCarthy et al. (26) and Morrison and de Vellis (27). After shaking, the medium containing the oligodendroglial cells was discarded and the cultures were washed twice in Ham's saline B. They were fed G3 glial medium as described by Bottenstein (28) for $3 \mathrm{~h}$, refed again with $\mathrm{G} 3$ medium for $5 \mathrm{~h}$; spent medium was discarded. The cultures were fed a third time with $\mathrm{G} 3$ medium to which cells were exposed for 5 days. After this time the glial conditioned G3 medium was collected and the cultures were refed with mouse astrocyte medium for 3 more days prior to repeating the conditioning process.

Preparation of $G C M$. The GCM was prepared from the expended G3 medium by centrifugation at $48,250 \times g$ for $1 \mathrm{~h}$ at $5^{\circ} \mathrm{C}$ and dialyzed for $48 \mathrm{~h}$ against two changes ( 200 volumes) of $0.01 \mathrm{M}$ ammonium acetate, $\mathrm{pH} 5.2$, at $4^{\circ} \mathrm{C}$ in dialysis tubing 
with a molecular weight cutoff of 3500 . The GCM was lyophilized and stored at $-70^{\circ} \mathrm{C}$ until used. For analysis the GCM was reconstituted in normal saline at $50 \mathrm{mg}$ solids $/ \mathrm{ml}(=3.25 \mathrm{mg}$ protein $/ \mathrm{ml}$ ) and filtered through a $0.22-\mu$ Millex filter (Millipore). Measurement of protein was performed by either of two methods $(29,30)$.

Bioassays. The bioassay, using the clonal rat pheochromocytoma cell line (PC-12) as described by Green (1), was used with the following exceptions: the plates were not coated with polylysine and the cells were not "primed" with NGF prior to the assay. The PC-12 cells were obtained from Dr. Lloyd Green and maintained in RPMI-1640 medium containing $10 \%$ heat-inactivated horse serum and $5 \%$ heat-inactivated fetal bovine serum. For the bioassay, both sera were omitted. The cells were harvested from logarithmic-growing cultures, washed three times with Ham's saline B, then resuspended in RPMI-1640 medium at a cell density of $2 \times 10^{4}$ cells $/ \mathrm{ml}$. One $\mathrm{ml}$ of the cell suspension was added to each well of six well cluster plates (Costar) having a surface area of $8 \mathrm{~cm}^{2}$. Three doses of GCM were used: 50,100 , and $200 \mu \mathrm{l}(162.5,325$, and $650 \mu \mathrm{g}$ protein, respectively). Rabbit anti- $\beta$-NGF having a titer of $1: 150,000$, as determined by radioimmunoassay, was diluted $1: 10$ and added at a single dose of $200 \mu \mathrm{l}$ (1:1500 final titer) to opposing wells containing the three doses of GCM. The total volume of each well was brought to 2 $\mathrm{ml}$ with the addition of RPMI-1640. The plates were incubated at $37^{\circ} \mathrm{C}$ in a humidified atmosphere of $5 \mathrm{CO}_{2} /$ air. The bioassay was read at 48 and $72 \mathrm{~h}$ and visually quantified as the percentage of neurite-bearing cells in the test wells in comparison to control wells.

$\left[{ }^{35} S\right]$ cystine labeling and immunoprecipitation. The labeling and immunoprecipitation were conducted as described by Berger and Shooter $(31,32)$. Subconfluent cultures in passage two (24 days in vitro) were detached with $0.25 \%$ trypsin and $0.02 \%$ EDTA in Tris buffer, pH 7.8. The trypsin was neutralized with soybean trypsin-inhibitor and the cells harvested by centrifugation at $800 \mathrm{rpm}$ for $10 \mathrm{~min}$. The resultant cell pellet was resuspended in the mouse astrocyte medium to a density of $2 \times 10^{5}$ cells $/ \mathrm{m}$. One $\mathrm{ml}$ of the cell suspension was added to each well in six well cluster plates. The plates were incubated overnight at $37^{\circ}$ $\mathrm{C}$ in humidified $5 \% \mathrm{CO}_{2}$ /air to effect cell attachment. The plating medium was then aspirated and discarded, the wells were rinsed twice with Ham's saline B, and $2 \mathrm{ml}$ of $\mathrm{G} 3$ medium were added to all wells and the plates returned to the incubator for $3 \mathrm{~h}$. The medium was aspirated and discarded. The cells were refed and incubated for a further $5 \mathrm{~h}$ after which time they were fed G3 medium containing $626 \mu \mathrm{g} / \mathrm{ml}$ cystine (as carrier) and returned to incubate.

The cultures were labeled at $24,48,72,96$, or $120 \mathrm{~h}$ after plating by adding $1 \mu \mathrm{Ci}\left[{ }^{35} \mathrm{~S}\right]$ cystine (specific activity $487 \mathrm{Ci}$ / $\mathrm{mM}$, New England Nuclear) to each well, incubating for $10 \mathrm{~min}$ at $37^{\circ} \mathrm{C}$ in $5 \% \mathrm{CO}_{2}$ /air, and following with a 150 -min pulse chase. At the completion of the pulse chase, $500 \mu \mathrm{l}$ from each supernatant were spotted on 2.4-cm glass filters (Whatman), precipitated with ice cold $10 \%$ TCA, washed with cold ethanol, and dried overnight at $37^{\circ} \mathrm{C}$ prior to counting. The remaining supernatants were collected into individual polystyrene $12 \times 75$ $\mathrm{mm}$ tubes, flash frozen in dry ice-ethanol, and lyophilized.

The cells were harvested from the wells by scraping with 500 $\mu$ l lysing homogenization buffer, $\mathrm{pH} 4.0$, and incubated in an ice bath for $10 \mathrm{~min}$ to effect lysis. The lysates were transferred to ice cold $1.5 \mathrm{ml}$ microfuge tubes (Beckman), sonicated for $1 \mathrm{~min}$, and centrifuged for $1 \mathrm{~h}$ at $48,250 \times g$ at $4^{\circ} \mathrm{C}$. The supernatants were removed and $20 \mu \mathrm{l}$ pretitered rabbit $\beta$-NGF antiserum (diluted 1:10) were added to each tube. The tubes were vortexed, incubated in an ice bath for $48 \mathrm{~h}$ at $4^{\circ} \mathrm{C}$, and centrifuged at $10,000 \times g$ for $5 \mathrm{~min}$ at $4^{\circ} \mathrm{C}$. The resultant immunoprecipitates were washed with an acetate wash buffer, $\mathrm{pH} 4.0$, dissolved in $250 \mu \mathrm{l} 0.1 \mathrm{~N} \mathrm{NaOH}$ and then neutralized with $250 \mu \mathrm{l} 0.1 \mathrm{HCl}$. To each of these tubes $55 \mu$ l of incubation buffer (sodium acetate $0.5 \mathrm{M}$ with $10 \mathrm{mg} / \mathrm{ml}$ bovine serum albumin, $\mathrm{pH} 4.0$ ) as a suspension, $20 \mu \mathrm{l} \beta$-NGF antiserum (1:10 dilution), and $30 \mu \mathrm{l} \beta$ NGF $(50 \mu \mathrm{g} / \mathrm{ml})$ as carrier were added. The mixture was incubated for $24 \mathrm{~h}$ at $4^{\circ} \mathrm{C}$. The immunoprecipitates were collected by centrifugation, washed once with $500 \mu \mathrm{l}$ wash buffer, and prepared for SDS-PAGE analysis.

The lyophilized supernatants were reconstituted to $250 \mu \mathrm{l}$ with wash buffer and immunoprecipitated in the same manner as the cell lysates.

$S D S-P A G E$ analysis. This analysis was performed by the method of Laemmli (34). The immunoprecipitates were incubated in $100 \mu \mathrm{l}$ modified sample buffer, pH 6.8 (Tris- $\mathrm{HCl} 0.0625$ $\mathrm{M}, \operatorname{SDS} 2 \%, 2$-mercaptoethanol $5 \%$, and urea $9 \mathrm{M}$ ), at $37^{\circ} \mathrm{C}$ overnight. The samples were run on acrylamide: bisacrylamide $(15: 0.375 ; 80 \times 5 \mathrm{~mm})$. Electrophoresis was performed using a Tris $(0.025 \mathrm{M})$, glycine $(0.192 \mathrm{M})$, SDS $(0.1 \%)$ buffer, $\mathrm{pH} 8.3$, and $4 \mathrm{~mA} / \mathrm{gel}$ until the dye front ran off the bottom of the gel $(6$ h). The gels were removed, cut into $2-\mathrm{mm}$ slices, and incubated overnight at $37^{\circ} \mathrm{C}$ in $8 \mathrm{ml}$ scintillation fluid (POPOP $4 \mathrm{~g}$, POP $0.05 \mathrm{~g}, 54 \mathrm{ml}$ PROTOSOL from the New England Nuclear, and $6 \mathrm{ml} \mathrm{H} \mathrm{H}_{2} \mathrm{O} /$ liter of toluene). The slices were counted in a multichannel liquid scintillation counter. Control gels containing purified $\beta$-NGF for staining and $\left[{ }^{125} \mathrm{I}\right] \beta$-NGF for slicing and counting were run at the same time in the system. The control gels were fixed in $50 \%$ TCA overnight, then stained at $37^{\circ} \mathrm{C}$ for $1 \mathrm{~h}$ in freshly prepared Coomassie B $(0.1 \%)$ in $50 \%$ TCA, followed by destaining in $7 \%$ acetic acid. The SDS-PAGE analysis of the GCM was performed by destaining in 7\% acetic acid. The SDSPAGE analysis of the GCM was performed using 5-20\% linear gradient gels. Fifty $\mu \mathrm{l}$ of the immunoprecipitated GCM were incubated with $50 \mu \mathrm{l}$ of the modified sample buffer at $90^{\circ} \mathrm{C}$ for $10 \mathrm{~min}$. Fifty $\mu \mathrm{l}$ were loaded onto each of two of the linear gradient gels prerun for $30 \mathrm{~min}$. Electrophoresis conditions and buffer were as described previously. Control gels contained the following standards 1) phosphorylase, 2) bovine serum albumin, 3) ovalbumin, 4) carbonic anhydrase, 5) soybean trypsin inhibitor, 6) $\alpha$-lactalbumin, 7) aprotinin, and 8) insulin ( $\beta$-chain). Mouse $\beta$-NGF gels were run at the same time. The gels were fixed, stained, and destained as noted previously.

Gel filtration. This was performed as described by Furukawa et al. (20). Five hundred $\mu 1$ of GCM were applied to a $1 \times 50 \mathrm{~cm}$ Sephadex G-100 (Pharmacia) column preequilibrated with 0.1 $\mathrm{M}$ phosphate buffer, $\mathrm{pH} 7.0$, containing $0.3 \mathrm{M} \mathrm{NaCl}$ and $1 \mathrm{mM}$ $\mathrm{MgCl}_{2}$. The flow rate was $3 \mathrm{ml} / \mathrm{h}$ and $800 \mu \mathrm{l}$ fractions were collected. The fractions were screened for NGF activity by one site radioimmunoassay as described by Walker et al. (33). The fractions containing $\beta$-NGF were pooled, lyophilized, and subsequently tested for bioactivity. The column was calibrated for estimation of molecular weight using blue dextran, trypsinogen, and cytochrome $\mathrm{C}$. The column was then flushed and reequilibrated with buffer. [ $\left.{ }^{125} \mathrm{I}\right] \beta$-NGF $(10,000 \mathrm{cpm})$ was added and the column run as noted previously. The fractions were counted on a $\gamma$ counter.

\section{RESULTS}

The mouse cerebral cells cultured in a modified astrocyte medium assumed the same morphology as similar cells grown in serum containing medium. However, upon subsequent passage they tended to grow as clusters, eventually spreading and flattening out. Growth rates tended to be somewhat slower in the modified medium. Histochemical studies of this cell line showed a glutamine synthetase level equal to that found simultaneously in a rat astrocyte cell line known to be free of meningeal fibroblast contamination. Similarly, histochemical and immunofluorescent studies revealed at least $80 \%$ of cells to contain glial fibrillary protein. Considering that newly replicated astrocytes in a developing astrocyte culture may not show a positive reaction for glial fibrillary protein, these findings are highly suggestive that the culture is composed predominantly of astrocytes. In addition, because meningeal cells rarely thrive in the medium described, 
and because our attempts to grow postnatal mouse skin fibroblasts in the medium were unsuccessful, we conclude that our cultures are composed predominantly of mouse brain astrocytes. We cannot, however, exclude the possibility of minimal contamination with meningeal cells.

The PC-12 bioassay was performed to determine the neurite promoting and neuronal survival properties of the GCM. A low density culture $\left(1 \times 10^{4}\right.$ cells/well $)$ of rat pheochromocytoma cells (PC-12) was treated with the reconstituted GCM added at 50,100 , and $200 \mu \mathrm{l}$ (with opposing wells receiving the same doses); a single dose of $200 \mu \mathrm{l}$ rabbit anti- $\beta$-NGF was used to block any NGF-mediated effect. The resultant neurite outgrowth effect with GCM was directly dose dependent. Representative plates with $200 \mu \mathrm{l} \mathrm{GCM}$ from 2- and 12-day astrocyte cultures are shown in Figure $1 b$ and $c$. The effect of purified NGF (50 $\mathrm{ng} / \mathrm{ml}$ ) is shown in Figure $1 a$. The wells containing 50 and 100 $\mu \mathrm{l}$ GCM were completely blocked by the $\beta-\mathrm{NGF}$ antiserum. A representative plate from 2-day astrocytes and $100 \mu \mathrm{l}$ GCM blocked with antibody is shown in Figure $1 d$; the wells containing $200 \mu \mathrm{l} \mathrm{GCM}$ were not completely blocked.

The kinetics of NGF-LF synthesis and secretion by the astroglial cells were characterized by labeling and immunoprecipitation experiments. After pulse-chase labeling with $\left[{ }^{35} \mathrm{~S}\right]$ cystine at 24 , $48,72,96$, and $120 \mathrm{~h}$ (Fig. 2), there was a lag period of about 48 $\mathrm{h}$ before significant labeling of NGF-like immunoprecipitable material in cell lysates was observed. Label incorporation increased rapidly through $72 \mathrm{~h}$, plateaued, and fell off rapidly thereafter. Using TCA precipitation, secretion into the medium increased slowly to 96 with maximal levels of medium TCA precipitable label between 96 and $120 \mathrm{~h}$ (not shown).

The SDS-PAGE results are shown in Figure 3. A 5-20\% linear gradient was utilized. Both the 2- and 12-day GCM (tubes 3 and 4) showed large molecular weight, poorly resolved components of considerable concentration. In addition, however, each showed a faintly staining band migrating similarly to the purified mouse $\beta$-NGF standard (tube 2 ). The $\beta$-NGF standard ran near the $\alpha$-lactalbumin marker (faint band 6 , tube 1). The aprotinin and $\beta$-chain insulin standards ran off the gels.

The SDS-PAGE $(15 \%)$ gels run with $\left[{ }^{35} \mathrm{~S}\right]$ cystine labeled GCM, unlabeled $\beta$-NGF, and iodinated $\beta$-NGF are shown in Figure 4 . These three components ran at the same relative front on the gels. Because of low counts with cystine-labeled GCM, only one slice contained sufficient counts above background to be considered.

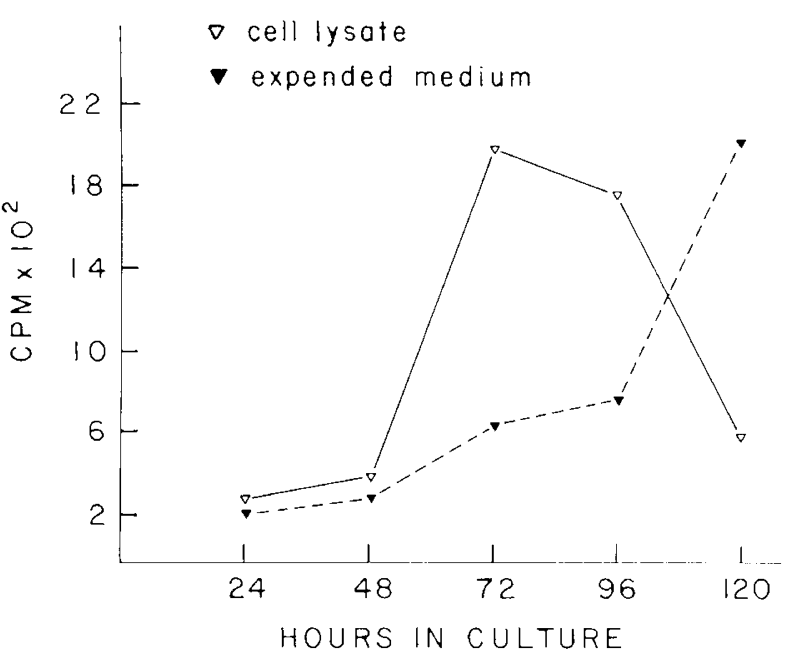

Fig. 2. $\left[{ }^{35} \mathrm{~S}\right]$ cystine pulse-chase cell lysate $(\triangle)$ and expended medium (ム) precipitated with $\beta$-NGF antiserum at $24,48,72,96$, and $120 \mathrm{~h}$ of culture.
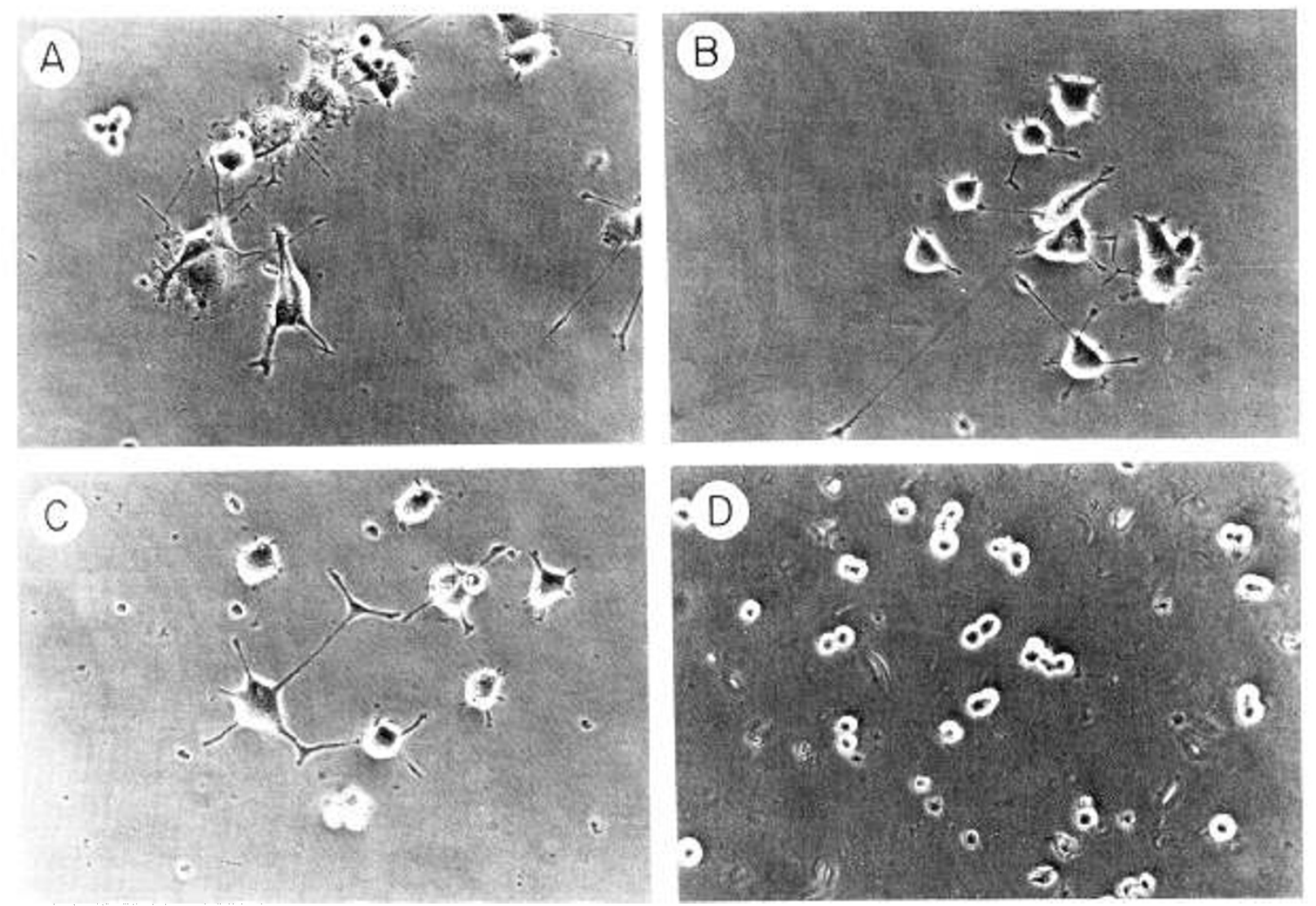

Fig. 1. Bioassay with PC-12 cells plated at a density of $2 \times 10^{4}$ cells $/ 2 \mathrm{ml} . A, \beta-\mathrm{NGF}, 50 \mathrm{ng} / \mathrm{ml} ; B, \mathrm{GCM} 2,200 \mu \mathrm{l}, 650 \mu \mathrm{g} \mathrm{protein} / \mathrm{ml} ; C, \mathrm{GCM}$ $12,200 \mu \mathrm{l}, 650 \mu \mathrm{g}$ protein $/ \mathrm{ml} ; D, \mathrm{GCM}-2,100 \mu \mathrm{l}, 325 \mu \mathrm{g}$ protein $/ \mathrm{ml}+\beta$-NGF antibody. All parts $\times 200$. 


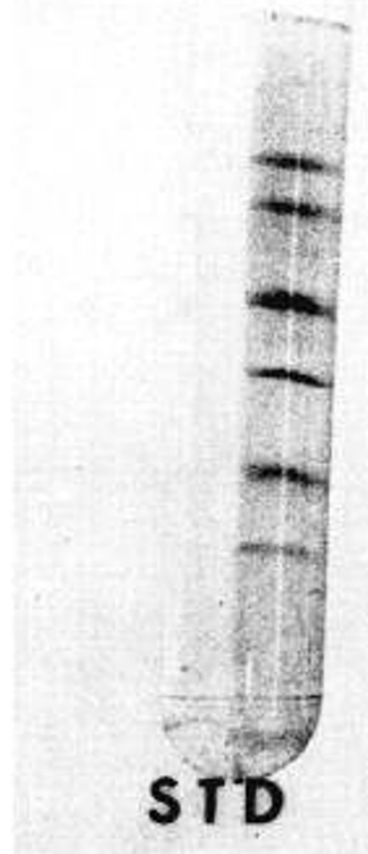

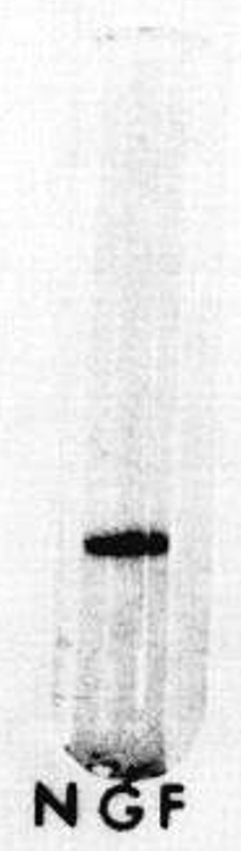

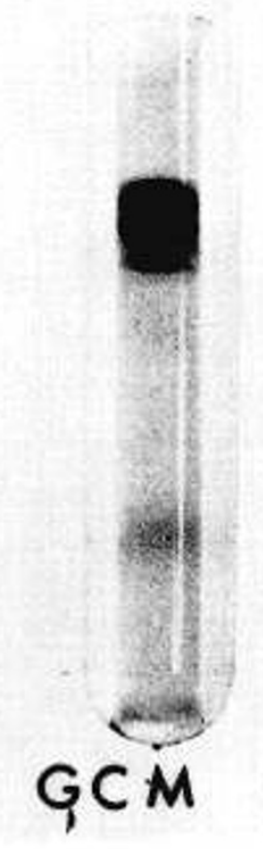

2

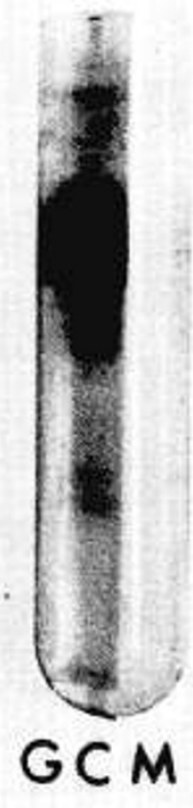

12

Fig. 3. SDS-PAGE 5-20\% lincar gradient gels run at $4 \mathrm{~mA} /$ gel in Tris-glycine-SDS, pH 8.3. The standard (STD) markers from top to bottom were phosphorylase, bovine serum albumin, ovalbumin, carbonic anhydrase, soybean trypsin inhibitor, and $\alpha$-lactalbumin (faint band roughly equivalent to NGF band in tube 2). Tubes 3 and 4 show GCM from 2 day and 12 day cells, respectively.

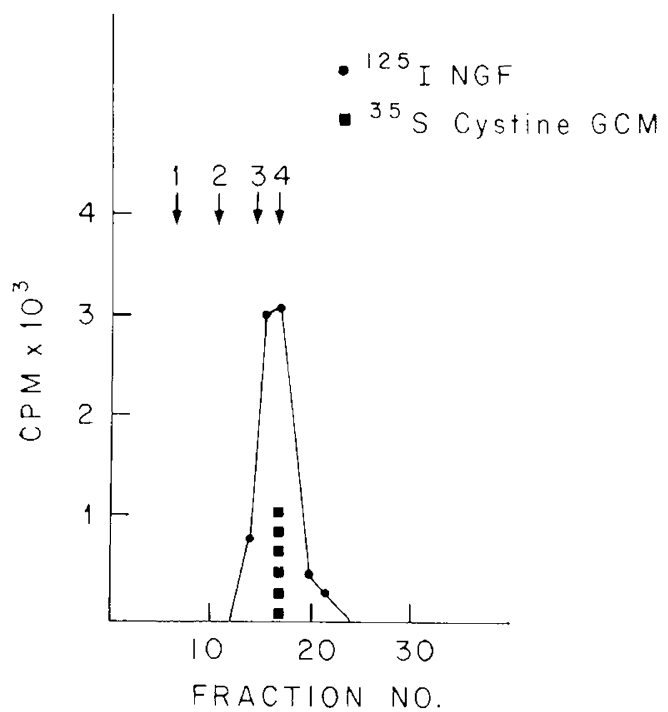

Fig. 4. SDS $15 \%$ PAGE gels run with $\left[{ }^{125} \mathrm{I}\right] \beta$-NGF $(\bullet)$ and $\left[{ }^{35} \mathrm{~S}\right]-$ cystine GCM immunoprecipitated with $\beta$-NGF antiserum (घ) 2-mm slices. Standards represented are 1 . carbonic anhydrase; 2 , trypsin inhibitor: 3, lysozyme; and 4, cytochrome C.

Analytical gel filtration of the GCM $\beta$-NGF immunoreactivity and $\left[{ }^{125} \mathrm{I}\right] \beta$-NGF gave similar elution patterns, the peaks being one fraction apart (Fig. 5). Both the $\left[{ }^{[25} \mathrm{I}\right]$ NGF and the $\beta$-NGF immunoreactivity eluted between the trypsinogen and cytochrome C markers. These peak fractions $(29,30,31)$ showed

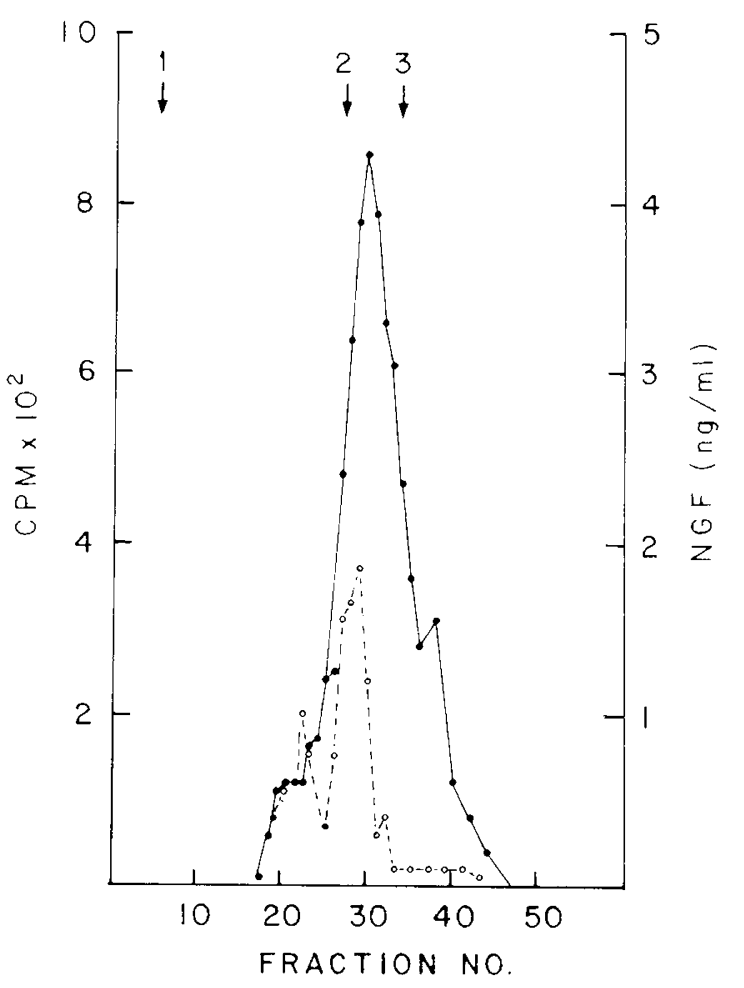

Fig. 5. Sephadex G-100 chromatogram $(1 \times 50 \mathrm{~cm})$ with $\mathrm{PO}_{4}-\mathrm{NaCl}-$ $\mathrm{MgCl}_{-2}$ buffer, pH 7.0: ${ }^{125} \mathrm{I} \beta$-NGF $(\mathrm{O})$ and $\mathrm{GCM}(\bullet)$. Marker standards 1 , blue dextran; 2 , trypsinogen; and 3 , cytochrome $\mathrm{C}$. 
approximately $4 \mathrm{ng} / \mathrm{ml}$ of NGF-like material by radioimmunoassay. The pooled peak fractions demonstrated bioactivity with the PC-12 bioassay after elution from the column. Analysis of the area under the GCM elution peaks gave a yield of about 45 ng immunoreactive NGF-like material. The shoulder on the iodinated NGF peak is assumed to be aggregated material.

\section{DISCUSSION}

The results of this study indicate that newborn mouse astrocytes in culture produce several proteins identifiable in the conditioned culture medium. The SDS-PAGE linear gradient gels show at least seven protein components, five minor and two major, with a molecular weight range (in the reduced form) of approximately 80,000 to 12,000 daltons (Fig. 3). The minor bands in the 2- and 12-day GCM ran similarly to purified mouse submandibular gland $\beta$-NGF and $\alpha$-lactalbumin, suggesting a molecular weight approximating 12,000 daltons and a migration pattern similar to purified $\beta$-NGF. This was further supported by the identical mobility of the ${ }^{35}$ S-cystine labeled GCM and ${ }^{125}$ I-NGF on the 15\% PAGE gels (Fig. 4) and the similar peaks of NGF immunoreactivity in GCM and ${ }^{125}$ I-NGF on analytical gels (Fig. 5).

Pulse chase labeling studies showed progressive labeling of cellular NGF-LF over $72 \mathrm{~h}$ with secretion into GCM between 96 and $120 \mathrm{~h}$ (Fig. 2). The PC12 bioassay of GCM in the 50 and $100 \mu \mathrm{l}$ volumes demonstrated neurite outgrowth which was inhibited by NGF antiserum. The $200-\mu \mathrm{l}$ antiserum dose did not inhibit bioactivity in the $200 \mu \mathrm{l} \mathrm{GCM}$ samples (Fig. 1), and larger doses were not used. Nonetheless these results clearly indicate NGF-like bioactivity in GCM of both 2- and 12-day astrocytes in culture.

We conclude from these results that astrocytes in developing mouse brain produce a peptide with biochemical, biological, and immunological characteristics similar to mouse submaxillary gland $\beta$-NGF. Such results have not been published previously. In the SMG, NGF is produced as a large $7 \mathrm{~S}$ complex which is dissociated to subunits at a concentration less than $1 \mu \mathrm{g} / \mathrm{ml}(35)$. Whether the NGF-like material in our culture system is produced as a $7 \mathrm{~S}$ complex is not clear; we have not further characterized the cellular or conditioned material. If the astrocyte NGF is produced as a $7 \mathrm{~S}$ complex, it may be rapidly dissociated to the active $\beta$-NGF subunit in the culture medium.

Norrgren et al. (21) previously addressed the issue of whether NGF is secreted by brain cells by studying a normal human astrocyte-like glial cell line. These investigators detected release from the cell pellet and GCM of a factor similar in biological activity and immunological properties to mouse NGF. Although suggestive of production of an NGF-like factor from human glial cells in vitro, these results were inconclusive since GCM was not subjected to radioimmunoassay and chromatography analyses were not conducted.

The significance of NGF in central nervous tissue is not clear. A series of recent in vivo studies have suggested that endogenous CNS NGF and its receptor may be important for the function of cholinergic neurons. Developing cholinergic neurons of both the basal forebrain and striatum respond to NGF injections (36). Although neurons from these two areas are anatomically and physiologically dissimilar, the fact that both neuron types respond to NGF is of interest. Since NGF does not cross the blood brain barrier, these recent findings further support the likelihood that NGF is produced within CNS tissue. The present results indicating in vitro synthesis and secretion of an NGF-like factor in CNS astroglial cells are supportive of the potential role of NGF in the CNS. Our results also provide direct evidence that an NGF-like factor is produced by neonatal brain astrocytes so that a role in brain development is possible.

Acknowledgments. The authors thank $\mathrm{H}$. Kim for expert technical assistance and Prescilla Barrette for preparation of the manuscript. We are grateful to Dr. Jean de Vellis, Dr. Russ Saneto, Sheila Scully, and Yair Aizenman of the Laboratory of Biomedical and Environmental Sciences at UCLA for the histochemical, immunofluorescence, and the enzyme studies.

\section{REFERENCES}

1. Green LA 1977 A quantitative bioassay for nerve growth factor (NGF) activity employing a clonal pheochromocytoma cell line. Brain Res 133:350-353

2. Walker PE, Weichsel ME Jr, Fisher DA, Guo SM, Fisher DA 1979 Thyroxine increases nerve growth factor concentration in adult mouse brain. Science 204:427-429

3. Johnson DG, Gorden P, Kopin IJ 1971 Sensitive RIA for 7S antigens in serum and tissue. $J$ Neurochem 18:2355-2362

4. Hendry IA 1972 Developmental changes in tissue and plasma concentrations of the biologically active species of nerve growth factor in the mouse, by using a two site radioimmunoassay. Biochem $\mathbf{J}$ 128:1265-1272

5. Shine HD, Perez-Polo $J_{r} 1976$ Nerve growth factor protein in golden hamster. J Neurochem 27:1315-1318

6. Walker P, Weil ML, Weichsel ME Jr, Fisher DA 1981 Effect of thyroxine on nerve growth factor in neonatal mouse brain. Life Sci 28:1777-1787

7. Scott SM, Tarris RH, Eveleth D, Weichsel ME Jr, Fisher DA 1981 Bioassay detection of mouse nerve growth factor (NGF) in the brain of adult mice. $J$ Neurosci Res 6:653-658

8. Levi-Montalcini R, Hamburger V 1953 A diffusible agent of mouse sarcoma producing hyperplasia of sympathetic ganglia and hyperneurotization of visera of chick embryo. J Exp Zool 123:233-288

9. Murphy RA, Oger J, Saids JD, Blanchard MH, Arnason BGW, Hogan C, Panzis NJ, Young M 1977 Secretion of nerve growth factor by central nervous system glioma cells in culture. J Cell Biol 72:769-773

10. Murphy RA, Pantazis NJ, Arnason BGN, Young M 1975 Secretion of a nerve growth factor by mouse neuroblastoma cells in culture. Exp Cell Res 130:3139

11. Oger J, Arnason BGW, Pantazis NJ, Lehrich J, Young M 1974 Synthesir of nerve growth factor by L and 3T3 cells in culture. PNAS 71:1554-1558

12. Murphy RA, Singer RH, Saide JD, Pantazis HN, Blanchard MH, Byron KS Arnason BGW, Young M 1977 Synthesis and secretion of a high molecular weight form of nerve growth factor by skeletal muscle cells in culture. PNAS 74:4496-4500

13. Schwartz JP, Breakefield XO 1980 Altered nerve growth factor in fibroblasts from patients with familial dysautonomia. PNAS 77:1154-1158

14. Varon S, Raiborn C, Norr S 1974 Association of antibody to nerve growth factor with ganglion non-neurons (glia) and consequent interference with their newborn-supportive action. Exp Cell Res 88:247-256

15. Young $\mathrm{M}$, Oger J, Blanchard MH, Asdourian H, Amos $\mathrm{H}$, Arnason BGW 1974 Secretion of a nerve growth factor by primary chick fibroblast cultures. Science 187:361-362

16. Harper GP, Pearce FL, Vernon CA 1976 Production of nerve growth factor by the mouse adrenal medulla. Nature 261:251-253

17. Ebendal TA, Jordell-Kylber A, Soderstrom A 1978 Form shaping movements in a neurogenesis. In: Jackson CO, and Ebendal TA (eds) neurogenesis. Almquist and Wiksell, Stockholm pp 235-243

18. Harper GP, Al-Soffer AM, Pearce FL, Vernon CA 1980 The production of nerve growth factor in vitro by tissues of the mouse, rat, and embryonic chick. Dev Biol 77:379-390

19. Chun LLY, Patterson PH 1977 Role of nerve growth factor in the development of rat sympathetic neurons in vitro, III. Effect of acetylcholine production. J Cell Biol 75:712-718

20. Furukawa Y, Furukawa S, Satoyoshi E, Hayashi K 1984 Nerve growth factor secreted by mouse heart cells in culture. J Biol Chem 259:1259-1264

21. Norrgren G, Ebendal T, Below M, Jacobsen CO, Porath J 1980 Release of nerve growth factor by human glial cells in culture. Exp Cell Res 130:31-39

22. Honegger P, Richelson E 1976 Biochemical differentiation of mechanically dissociated mammalian brain in aggregating cell culture. Brain Res 109:335354

23. Samuels H, Herbert H, Stanley F, Casonova J 1979 Depletion of L-3, 5-3'. triiodothyronine and $\mathrm{L}$-thyroxine in euthyroid calf serum for use in cell culture studies of the action of thyroid hormones. Endocrinology 105:80-85

24. McKeehan WL, Hamilton WG, Ham RA 1976 Selenium is an essential nutrient for growth of WI-38 diploid human fibroblasts. PNAS 73:20232027

25. Fisher G 1982 Cultivation of mouse brain cells in defined media. Investigation of selective conditions for astroglia. Cold Spring Harbor Conferences on Cell Proliferation. Cold Spring Harbor Laboratory, Cold Spring Harbor, NY 9:1068-1073

26. McCarthy K, de Vellis J 1980 Preparation of separate astroglial and oligodendroglial cell cultures from rat cerebral tissue. J Cell Biol 85:890-902

27. Morrison R, de Vellis J 1981 Growth of purified astrocytes in a chemically defined medium. PNAS 78:7205-7209

28. Bottenstein JE 1983 Growth requirements of neural cells in vitro. Adv Cell Neurobiol 4:333-379

29. Lowry OH, Rosebrough NJ, Farr AL, Randall RJ 1951 Protein measurement with the folin phenol reagent. J Biol Chem 193:265-275

30. Bradford M 1976 A rapid and sensitive method for the quantitation of microgram quantities of protein utilizing the principle of protein-dye binding. Anal Biochem 72:248-254 
31. Berger E, Shooter EM 1977 Evidence for pro $\beta$-nerve growth factor, a biosynthetic precursor to $\beta$-nerve growth factor. PNAS 74:3647-3651

32. Berger E, Shooter EM 1978 Biosynthesis of $\beta$-nerve growth factor in mouse submaxillary glands. J Biol Chem 253:804-810

33. Walker P. Weichsel ME Jr, Guo SM, Fisher DA 1980 Radioimmunoassay for mouse nerve growth factor (NGF): effects of thyroxine administration of tissue NGF levels. Brain Res 186:331-341
34. Laemmli UK 1970 Cleavage of structural proteins during the assembly of the head of bacteriophage T4. Nature 227:680-685

35. Young M, Saide JD, Murphy RA, Arnason BGW 1976 Molecular size of nerve growth factor in dilute solution. J Biol Chem 251:459-464

36. Mobley WG, Rutkowski JL, Tennekoon GI, Buchanan K, Johnston MW 1985 Choline acetyl transferase activity in striatum of neonatal rats increased by nerve growth factor. Science 229:284-287 